\title{
Does Distance Matter for Trade in Services? The Case of Interprovincial Trade in Canada
}

\section{Catherine Boulatoff $^{1} \cdot$ Talan B. İşcan $^{1} \cdot$ Yulia Kotlyarova $^{1}$}

Accepted: 7 July 2021 / Published online: 2 November 2021

(C) The Author(s), under exclusive licence to Springer Science+Business Media, LLC, part of Springer Nature 2021

\begin{abstract}
We examine the impact of geographic distance, economic size, and jurisdictional borders on Canadian interprovincial trade in services at the industry level. Using a gravity model, we find that the average elasticity of service trade with respect to distance is -1.1 , which coincides with the median estimate of average elasticity of merchandise trade with respect to distance. However, the point estimates of the elasticity of distance are significantly higher in magnitude in Arts and Health, while distance matters much less for Telecommunications and Information Technology. We also find that the elasticity of trade with respect to exporter and importer gross domestic product is highly industry specific. Our findings suggest that distance is still a key determinant of service trade and the income elasticity of demand is heterogeneous within the service sector.
\end{abstract}

Keywords Trade in services · Interregional trade - Distance effect · Gravity model Canada

JEL Classification F10 $\cdot$ R11

\section{Introduction}

National economies have become increasingly more service oriented (Fuchs 1968; Schettkat and Yoncarini 2006). This has led to two different views about the future

Yulia Kotlyarova

yulia.kotlyarova@dal.ca

Catherine Boulatoff

Boulatoff@dal.ca

Talan B. İşcan

tiscan@dal.ca

1 Department of Economics, Dalhousie University, Halifax, NS, B3H 4R2, Canada 
of global trade, which has historically been dominated by trade in commodities and manufactured goods (Findlay and O'Rourke 2007). According to one view, services require prohibitively high transportation costs (think haircuts), and as the share of national output in services increases, global trade will slow down and even shrink as a share of global GDP (Lewis et al. 2018). According to the more sanguine view of global trade, however, as the shares of manufacturing and agriculture in GDP decline, services will be the main source of growth in global trade, an expectation in part due to the assumption that transportation, insurance, and storage costs may be overall lower for services (Goldfarb 2013; Palladini 2015) and in part due to the momentum created by the 1995 General Agreement on Trade in Services (World Trade Organization 2013; Francois and Hoekman 2010).

Given the merits of each viewpoint, the determinants of global trade in services have attracted growing attention. Recent comparisons of firms in manufacturing and service sectors show that service firms on average have relatively lower export participation rates, a higher return to size, and lower survival rates in export markets (Tito 2019). Available estimates suggest that impediments to cross-border gross trade in services are higher than those in goods sectors, in many cases by a multiple of two to three (Miroudot et al. 2013), and ad valorem equivalents of costs that are inferred to impede trade in services are on average very high — as high as $2,000 \%$ in several industries (Benz 2017), though these cost estimates are higher for gross trade as opposed to value-added trade (Duval et al. 2015). While these findings reinforce the traditional treatment of the service sector output as internationally non-traded, there is still considerable uncertainty about the drivers of cross-border trade in services.

In this paper, we contribute to the body of literature on trade in services by examining the impact of geographic distance, jurisdictional borders, and economic size on Canadian interprovincial trade in services at the industry level from 2007 to 2013. Using a gravity model, we find that the average elasticity of trade in services with respect to distance is -1.1 , which coincides with the median estimate of average elasticity of merchandise trade with respect to distance (Head and Mayer 2014). However, we also find considerable heterogeneity across industries: the point estimates of service trade elasticity of distance are significantly higher in Arts and Health, while distance matters much less for Telecommunications and Information Technology. Distance matters for interregional trade even in industries such as Finance, Leasing, and Software. This relatively high estimate of the elasticity of service trade with respect to distance emerges in a context where cross-border service trade is fairly strong and has increased slightly over time. The strong negative association between distance and service trade may thus temper the views of those who see services as the new frontier in global trade.

While the impact of distance on cross-border merchandise trade has been extensively studied, direct evidence on the impact of distance on trade in services by industry is surprisingly limited (Kimura and Lee 2006; Walsh 2008; Anderson et al. 2014). Part of the reason is that service trade across national borders is poorly tracked, and we lack comprehensive international data on trade in services (Francois and Hoekman 2010), let alone bilateral data that can be used to estimate the elasticity 
of international trade in services with respect to distance at the industry level. ${ }^{1}$ Our high-quality data address the limitations of available international data on bilateral trade in service industries.

Distance is of course one of the determinants of service trade. Trade in services might also be driven by "border" effects, first identified by McCallum (1995) in the case of cross-border manufacturing trade and verified since by others (Helliwell 1997; Head and Mayer 2014). While often difficult to identify individually, the border effect tends to capture factors such as region-specific information, tastes, social and distribution networks, and agglomeration economies. ${ }^{2}$ Our estimates suggest that interprovincial trade in services is not driven by border effects. In all our model specifications, the effect of interprovincial border on trade in services is statistically insignificant. $^{3}$

Our estimates are based on interprovincial trade data that exhibit considerable concentration of service trade in terms of both regional and industrial specialization: the top three destinations of service exports from a region typically account for more than $70 \%$ of total service exports, and the top three service industries account for over $60 \%$ of total service exports from any given region. Even after controlling for exporter and importer region fixed effects common to all industries and years, our estimates show that the elasticity of trade with respect to exporter and importer GDP is highly industry specific.

Another reason typically put forward to account for trade in services is trade policies (Francois and Hoekman 2010). There is considerable evidence showing that restrictive trade policies have non-negligible impact on trade (Miroudot and Shepherd 2014; Gervais 2018). Beyond trade policy, country-level differences in regulatory measures may also affect trade flows (Kox and Nordås 2007; van der Marel 2016a). Our use of interprovincial data on service trade minimizes the impact of trade policy and differences in regulatory measures, and our analysis shows that international trade in services may be affected by geographic distance, above and beyond those imposed by national trade policies and regulations.

Our research complements a number of studies that explores several dimensions of trade in services. Based on bilateral trade in services of 10 OECD countries with other economies (1999-2000), Kimura and Lee (2006) compare the estimates for total service trade with those from merchandise trade, and find that distance has a greater impact on bilateral trade in services. Using OECD data for the period 1999-2001 period, Walsh (2008) finds that the gravity model fits both service and merchandise trade flows equally well, although there does not appear to be an independent

\footnotetext{
${ }^{1}$ Maurer et al. (2016) discuss conceptual and measurement issues that arise in tracking international service trade flows and document the growth trends in global trade in services. Wernerheim and Waples (2013) document the geographic concentration of Canada's trade in services, but such data are not available at the industry level and on a bilateral basis for most countries.

${ }^{2}$ In the case of Japan, for instance, Wrona (2017) finds that region-specific agglomeration economies determine a considerable border effect between East- and West-Japan.

${ }^{3}$ Our estimate of the border effect does not rule out the possibility that restrictions on personal movement may impact trade in services. International and interprovincial travel restrictions in Canada during the Covid-19 pandemic have, for example, demonstrated the significance of even provincial borders for tourism and travel related services.
} 
impact of distance on service flows across international borders. Also, van der Marel (2016b) compares Canada's geographic concentration of exports in services and in goods using a gravity model. Nordås (2018) uses the gravity model to study the intraNordic service trade. Anderson et al. (2014) use industry-level interprovincial and Canada-US bilateral trade data from 1997 to 2007, and compare the impact of an international border and distance on trade in goods versus services. They find that an international border reduces all trade, and distance has a relatively more negative impact on trade in services compared to goods.

The rest of the paper is organized as follows. Section 2 provides a context for our empirical analysis by summarizing the trends in service trade across provincial and territorial borders. Section 3 outlines our gravity model and discusses several empirical and theoretical aspects of our specifications. Section 4 presents our empirical findings. Section 5 concludes. A data Appendix and Supplementary material complement the main text.

\section{Interprovincial Trade in Services}

We contextualize the Canadian interregional trade in service industries along several dimensions: service trade by region; industry size and growth; interindustry growth; and diversification by markets and sectors. Our data source is the interprovincial input-output (IO) tables (Cansim Table 12-1-0088-01, formerly Cansim Table 3860003), which report sales by industry and by origin and destination for all Canadian provinces and territories (Supplementary material Table S.1). In this study, we use sales data from 2007 to 2013, all measured in basic prices (current dollars). ${ }^{4}$ In the interprovincial IO tables, inter-regional trade flows are based on the principle of resident to non-resident transactions (consistent with the principles underlying the balance of payments accounts). As a result, sales distinguish between services delivered outside and within the permanent residence of transactors. For our purposes, residence corresponds to a province or a territory.

The industry classifications we use are listed in Table 1 . The industry classifications underlying the interprovincial IO tables have historically been compatible with the guidelines provided by the System of National Accounts (SNA), and the most recent data available from Statcan uses SNA 2008 (Statistics Canada 2013). Within the IO tables, the industry classification structure is organized according to three broad sectors of the economy: business, government, and non-profit organizations

\footnotetext{
${ }^{4}$ Interprovincial data are collected, processed, and maintained by Statistics Canada (Statcan) in collaboration with Industry Canada under the Project to Improve Provincial Economic Statistics (PIPES). The main output of this project is a set of official provincial and territorial input-output (IO) tables, which contain the only detailed and comprehensive data on interprovincial trade in services. The source data underlying the IO tables originate from a variety of establishment surveys and administrative sources (Généreux and Langen 2002). While IO tables are available for earlier years (starting 1997), unfortunately, due to changes in methodology and product classification systems, it is not possible to reconcile earlier vintages of inter-provincial IO tables with the vintages we use here.
} 
Table 1 Interprovincial trade in services: industries

Total Service (3)

1. Accommodation and food services, $\mathrm{ACCO}$ (56)

2. Arts, entertainment and recreational services, ARTS (55)

3. Education services, EDUC (53)

4. Finance and Insurance, FINA $(45+46)$

5. Health, HEAL $(25+54+57+61)$

6 . Information and culture services, INFO (42)

7. Leasing, LEAS $(47+48)$

8. Merchanting, MERC $(39+40)$

9. Miscellaneous business, professional, and technical services, MISC $(9+13+49+51+52)$

10. Software, SOFT (50)

11. Telecommunications, TELE (44)

12. Transportation, TRAN $(41+62)$

Numbers in parentheses show industry numbers in the IO tables. Abbreviations used in figures below are also shown. Construction sector is excluded because all recorded construction sales are within the originating province. In a number of cases, we aggregate several industries to reduce incidence of zero bilateral trade in sub-industries, and work with classifications that are sufficiently homogeneous and yet interpretable. These more aggregate industry classifications are also immediately comparable with those sources that report international trade in services such as the Trade in Services Database (World Bank 2017)

Source: Cansim Table 12-1-0088-01

serving households (NPISHs). The business sector is further disaggregated by industry according to the North American Industrial Classification System (NAICS). ${ }^{5}$ Throughout we define interprovincial trade as value of sales originating from one Canadian region (province or territory) to all other regions.

Service Trade by Region Interprovincial IO tables include data on sales to (exports) and purchases from (imports) the rest of the world (RoW), but does not allow us to identify the origin and destination countries. ${ }^{6}$ Figure $1 \mathrm{~A}$ shows that both service exports to and imports from the RoW were affected by the recession of 2007-2009, but their shares in total service trade stabilized afterwards. Overall, interprovincial

\footnotetext{
${ }^{5}$ There are nevertheless differences between industries included in IO tables and in NAICS. In particular, the IO accounts "have established fictive industries as a routing mechanism. A number of goods and services originating in different industries, whose use is related to a common activity and for which there is limited statistical information on consumption, are grouped into fictive industries. Estimates are made of the commodity inputs into the fictive industries but no primary inputs are assigned to them, so their output is equal to their intermediate inputs" (Statistics Canada 2013, p.6). In any case, the Industry Accounts Division at Statistics Canada maintains concordances between NAICS 2007 and IO industrial classification system.

${ }^{6}$ See Boulatoff and İşcan (2018) for a discussion of the Canadian trade in services with individual countries. While the United States is overall a large partner of Canada in service trade, its significance varies across industries and over time.
} 


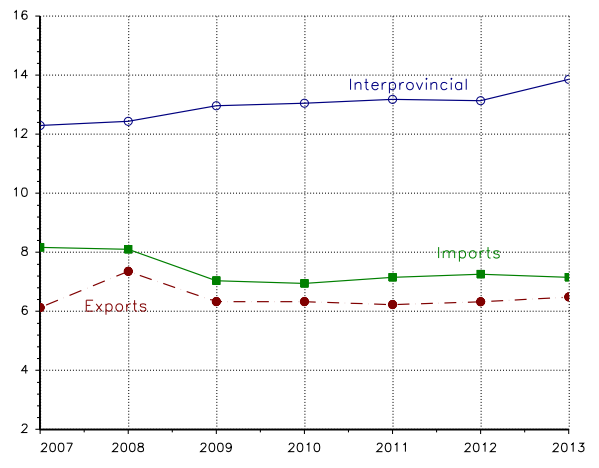

(A) Trade in services by year, $\%$

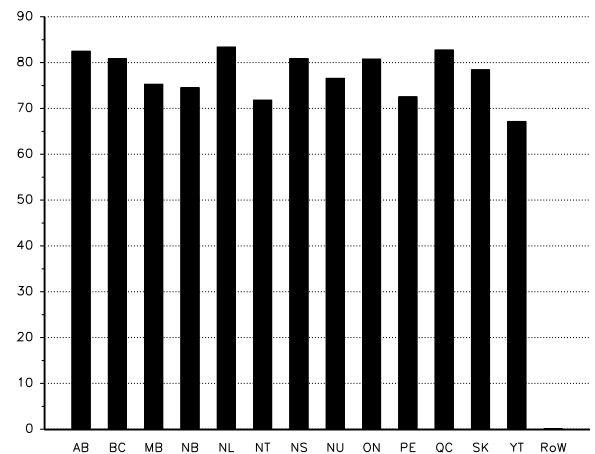

(B) Share of intraregional trade by region, $\%$

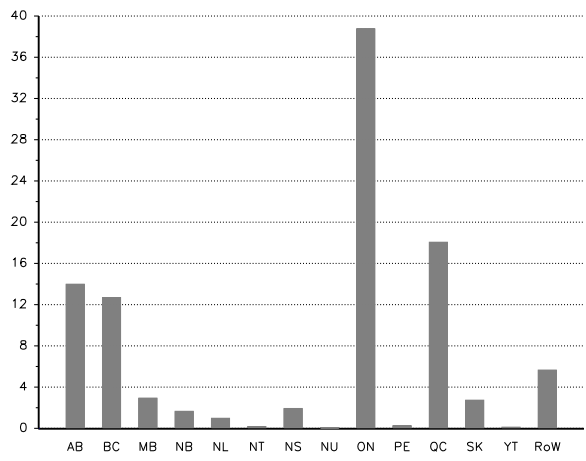

(C) Share of trade in services by region, $\%$

Fig. 1 Trade in services by region, 2007-2013. See Supplementary material Table S.1 for region abbreviations. Let $Q_{i j, t}^{h}$ represent sales from region $i$ to region $j$ in industry $h$. We use $w$ to represent the rest of the world (ROW), which is included here for completeness. A) Canadian service exports by year as a percentage of total service sales (dashed line with circles), the Canadian service imports as a percentage of total service sales (line with squares), and total interprovincial trade (exports $=$ imports) as a percentage of total service sales (solid line). Exports are $\sum_{h} \sum_{i} Q_{i w, t}^{h}$. Imports are $\sum_{h} \sum_{i} Q_{w i, t}^{h}$. Total Canadian service sales are $\sum_{i} \sum_{h}\left(Q_{i i, t}^{h}+\sum_{j \neq i} Q_{i j, t}^{h}+Q_{i w, t}^{h}\right)$. B) Intraregional service sales as a percentage of service sales over the period 2007-2013. Intraprovincial sales by region $i$ is $\sum_{h} Q_{i i, t}^{h}$ (similarly for the RoW). C) Regional service sales as a percentage of total service sales over the period from 2007 to 2013. Service sales by region $i$ in year $t$ is $\sum_{h} \sum_{j} Q_{i j, t}^{h}$ (similarly for the RoW). Source: Authors' calculations based on Cansim Table 12-1-0088-01

service trade experienced a slight increase over the 2007-2013 period, with a magnitude on par with total service trade (exports and imports) with the RoW. ${ }^{7}$ In our analysis, we only use interregional sales within Canada. Intraprovincial trade made up the bulk of Canadian trade in services at more than $70 \%$ (Fig. 1B).

\footnotetext{
${ }^{7}$ At least in terms of service trade, this represents a reversal of the trends observed in the 1990s; see Grady and MacMillan (1998).
} 
There were considerable differences in the value of services traded across Canadian regions. Figure $1 \mathrm{C}$ shows the regional weights underlying the Canadian tradein-services data. Compared to its share in provincial GDP (about 25\%), Ontario had a disproportionately higher share of service trade (40\%), likely due to its centrality in transportation and financial services and due to its relatively large manufacturing sector. Along similar lines, Quebec (20\% of national GDP) with its large manufacturing sector had the second largest share of service trade, while Alberta, which has a large natural resource sector, ranked third overall.

Industry Size and Growth Figure 2A shows the relative size of service industries. The three largest service industries were Leasing, Miscellaneous (which includes Miscellaneous Business, Professional, and Technical Services), and Merchanting, where the latter includes wholesale and retail services. Figure $2 \mathrm{~B}$ shows the average growth rate of sales in each service industry over the period 2007-2013. Education, Health, and Telecommunications, industries which tend to have a high income elasticity of demand, had the three highest growth rates. Transportation, by contrast, experienced a decline.

Diversification Interregional trade in services was highly concentrated in terms of both market destination and industry. Figure 3A shows, for each province and territory, the shares of the top three regions by sales destination (excluding intraprovincial sales). Notably, these shares exceeded $70 \%$ of the interregional trade of each region. The share of the top three industries was at least $60 \%$, reaching to about $80 \%$ in Newfoundland and Saskatchewan (Fig. 3B). A relative lack of diversity both in terms of market orientation and industry composition may be indicative of the significance of geographic proximity or economic size for trade in services.

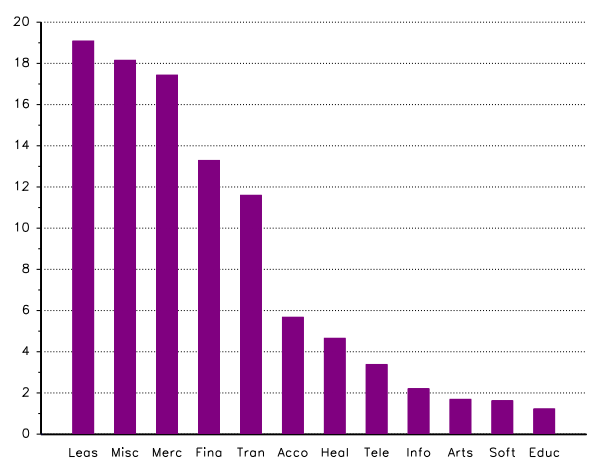

(A) Share of industry, \%

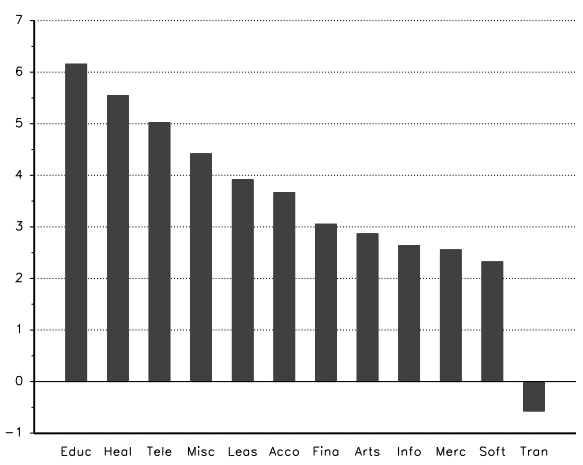

(B) Growth by industry, \%

Fig. 2 Trade in services by industry, 2007-2013. See Table 1 for the list of industries. A) Service industry sales as a percentage of service sales over the period 2007-2013. B) Average growth rate of service industry sales over the period 2007-2013 in percent. Source: Authors' calculations based on Cansim Table 12-1-0088-01 


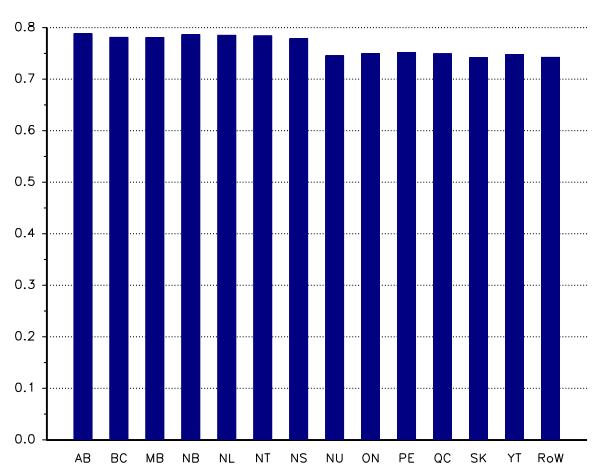

(A) Market diversification by region

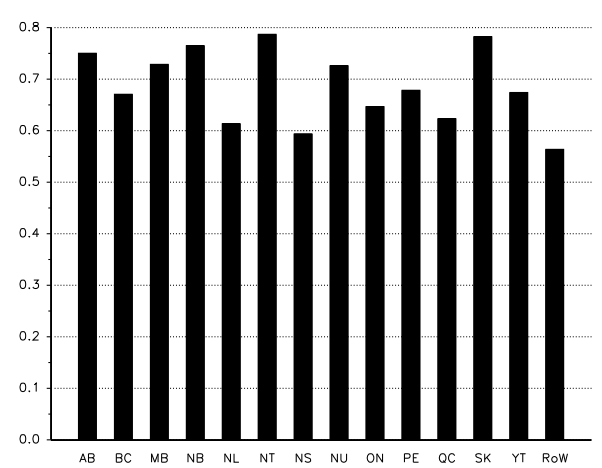

(B) Industry diversification by region

Fig. 3 Diversification of service trade by region, 2007-2013. See Supplementary material Table S.1 for region abbreviations, and Section S.2 for details. A) Share of top three regions in service industry sales to other regions averaged over the period 2007-2013. B) Share of top three service industries in total service industry sales to other regions over the period 2007-2013. Source: Authors' calculations based on Cansim Table 12-1-0088-01

\section{The Model}

We use a gravity model (Head and Mayer 2014) to investigate the impact of distance and border on regional service sales. Our dependent variable of interest is the logarithm of sales to region $j$ from region $i$ originating from industry $h$ in year $t, \ln Q_{i j, t}^{h}$, with $h=1,2, \ldots, 12, t=2007,2008, \ldots, 2013$. In terms of the origin (exporting) regions, we estimate our models using either all 13 provinces and territories or 10 provinces only. In terms of the origin (exporting) regions, we have $j=1,2, \ldots, 13(10)$ and $j \neq i$. We model all four dimensions of our data $(i, j, h, t){ }^{8}$ Our key independent variable is the distance between the origin $i$ and destination $j$ regions (Distance ${ }_{i j}$ ). We use a dummy variable (Border ${ }_{i j}$ ) that takes value 1 if $i$ and $j$ share a coastal or non-coastal provincial border. By construction, the distance and border variables are symmetric for each region pair.

Our empirical model includes independent variables $\left(\mathbf{X}_{i j, t}^{h}\right)$ that control for a range of factors that may influence bilateral service trade. The first set of variables controls for the size of the economies in the origin and destination regions: GDP per capita and total population, both in logarithms. ${ }^{9}$ We include the logarithm of regional consumer price indices (CPI) in both origin and destination regions to control for differential changes over time in prices across regions. We also include the fraction of population age 65 and above, the median age of the population, and the net annual

\footnotetext{
${ }^{8}$ Thus, for provinces and territories we have 7 years $\times 12$ industries $\times 13$ origin regions $\times 12$ destination regions $=13,104$ possible observations. For provinces only, 7 years $\times 12$ industries $\times 10$ origin provinces $\times 9$ destination provinces $=7,560$ possible observations.

${ }^{9}$ The model specification is equivalent to the one with the logarithms of GDP and total population, since $\log$ GDP per capita is a linear combination of $\log$ GDP and log population. This change of variables does not affect the coefficient estimates of the remaining regressors. Appendix A lists the data sources we use, provides more precise definitions of our variables, and correlations between our variables. See Table 6 for the shorthand references we use in subsequent tables.
} 
migration (as a fraction of total population) to control for differences across regions in demographic factors. Our final set of controls accounts for regional differences in fiscal policy (changes in monetary policy and fiscal policy at the federal level are common for all regions). We include two dummy variables: an election variable that takes value 1 if the region had a provincial election in that year ( 0 otherwise), and a government variable that takes value 1 if there is a change of governing political party or coalition. ${ }^{10}$ Finally, we allow for idiosyncratic events affecting destination-origin region and industry as a single unit.

We interpret distance as a barrier to trade in services, and border as a conduit to trade in services through "adjacency" or "contiguity" (Head and Mayer 2014). In the Canadian context, we expect that two regions which share a border are more likely to engage in cooperative agreements that reduce barriers to cross-border trade in services. While the gravity model is not normally derived by taking demographic structure and fiscal policy stance into consideration, we include two sets of variables to account for provincial differences and changes over time in demographic structure and fiscal policy stance. We expect trade in services, such as education and hospitality, to be sensitive to demographic structure-younger populations are more likely to have demand for educational services in other provinces and to travel more, and provinces with older populations tend to have their demand more skewed toward health services. We also expect an expansionary provincial fiscal policy change to have a positive impact on the demand for services (like engineering and architectural consulting services) in that province. These policy changes are likely to occur in years surrounding provincial elections after a change in governing party. By including a range of demographic and fiscal policy stance variables we also control for as much variation across provinces and territories as possible through economic variables as opposed to through fixed effects.

Our baseline specification is thus

$$
\ln Q_{i j, t}^{h}=\alpha_{1} \ln \text { Distance }_{i j}+\alpha_{2} \text { Border }_{i j}+\mathbf{X}_{i j, t}^{h} \beta+\delta_{i j}^{h}+u_{i j, t}^{h},
$$

where $\delta_{i j}^{h}$ is a destination-origin region and industry random effect, and $u_{i j, t}^{h}$ is an idiosyncratic error term. We augment this baseline specification by including year fixed effects common to all the region pairs and industries, industry fixed effects common to all the region pairs and years, and separate origin and destination region fixed effects common to all the industries and years.

Our choice of a random effects (RE) model at the industry-destination-origin unit level has the advantage over a fixed-effect (FE) specification in that it allows us to identify the impact of distance on bilateral trade. Moreover, when industry dummy variable, and origin and destination region (dummy) variables are included in the

\footnotetext{
${ }^{10}$ We do not include provincial government spending as a control variable, because a significant fraction of spending by provincial governments is on health and education, two industries that are included in our service trade data. While a similar point about possible endogeneity might also be made for regional GDP per capita, we note that this is less of a concern in our context given that our bilateral trade data are at the industry level, whereas GDP per capita is a provincial measure. Moreover, our research question is about the impact of distance on bilateral service trade. While we are agnostic about whether distance itself is endogenous, we nevertheless considered all possible controls that can be correlated with distance.
} 
specification, our estimates for time-varying regressors are almost identical to those from a pure fixed-effects model. ${ }^{11}$ Overall, this econometric specification achieves identification of the coefficients in a flexible setup.

A feature of bilateral international trade data is zero trade values reported by statistical agencies, either due to non-existing trade, missing values, or insignificant trade volume. In our context, despite the fact that all provinces and territories exhibit a high level of industry concentration (Fig. 3B), the vast majority of bilateral service trade values that are zero pertain to territory-to-territory or territory-to-province trade ( $Q_{i j, t}^{h}=0$ for 2,335 out of 13,104 possible observations). When we exclude the territories, which are relatively small regions, and consider trade in services between any two provinces only, the number of observations with zero trade values is 329 (about $4.3 \%$ of the possible observations). The remaining zeros are concentrated in several industries (Supplementary material Table S.2), and between small provinces. In our baseline specifications, observations with zero trade values are dropped. We address a potential sample-selection in a probit model (Supplementary material Table S.5) ${ }^{12}$

The baseline specification is parsimonious in the sense that we allow regressors to be common across all industries, and model industries with a time-invariant influence on bilateral service trade. However, one could be reasonably concerned about the homogeneity assumption underlying this specification for two reasons. While distance and border effects are related to transportation and transaction costs, it is difficult to argue that such costs are uniform across service industries. We also consider below additional specifications that are less restrictive-and thus more flexible - than our baseline specification.

We close this section by noting that size effects emerge in monopolistically competitive models that form the theoretical underpinnings of the gravity model and are absent in classical trade theories with perfect competition (Minford and Xu 2018). Because of the underlying assumptions about product differentiation across regions, these theories put different emphasis on demand versus supply determined trade flows. Service industries often offer highly differentiated products, like hospitality services that are located near a unique natural environment. Thus, a gravity model is a reasonable starting point to examine interprovincial trade flows in services.

\footnotetext{
${ }^{11}$ Technically, to address the concerns about potential correlation between regressors and individual effects, one typically runs the Hausman test by comparing RE and FE estimates. However, here, with year dummy variables in the model, a standard Hausman test is not applicable because the (asymptotic) variance matrix of the difference between the estimated coefficients is singular (Wooldridge 2010, p. 329). Instead, as suggested by Wooldridge (2010, p. 332), one can apply what is referred to as the Mundlak approach, whereby the original RE specification is augmented by a set of time averages of all time-varying regressors, and if one rejects the joint hypothesis that the time-average coefficients are zeros, then the RE specification would not be valid. In our model specification, all the time-varying regressors are characteristics of either an origin region or destination region. The corresponding time averages will be absorbed by the origin and destination region dummies (hence cannot be identified separately), and the estimated coefficients on the original time-varying regressors will be the same as in the FE specification.

${ }^{12}$ While Poisson pseudo maximum likelihood is an alternative to our RE model, it may yield downwardbiased (in absolute value) estimates of the elasticity of bilateral trade volume with respect to distance (Head and Mayer 2014).
} 


\section{Estimation Results}

We report our empirical findings using three complementary models, moving incrementally from the baseline specification to more flexible ones.

\subsection{Estimates for all Industries}

Table 2 reports the panel data estimation results for Eq. 1 separately for all provinces and territories (columns 1-4) and the ten provinces (columns 5-8). The reported coefficient estimates represent effects averaged over origin-destination pairs and industries. Estimation results in columns 1 and 5 include random effects (RE) by a pair of provinces and origin industry ("unit"). Columns 2 and 6 include unit RE and year fixed effects (FE); columns 3 and 7 include unit RE, year FE, and industry FE; and columns 4 and 8 include unit RE, year FE, industry FE, and separate exporter and importer FE. ${ }^{13}$ For inference, we use cluster-robust standard errors clustered by symmetric regional pairs $(i j$ and $j i$ combinations for any industry $h$, and there are 78 of such clusters).

Regardless of whether we consider provinces and territories or provinces only, and regardless of the model specification, distance matters for trade in services (from a high of -0.68 to a low -1.01$).{ }^{14}$ Our point estimates of the effect of a border are statistically indistinguishable from zero. We find positive effects on bilateral trade in services by the level of GDP per capita in the origin region and by the destination populations. Notably, a provincial election in the origin region tends to reduce interregional trade ( $p$-values $\leq 0.027$ ), while a change in government is not associated with a change in bilateral trade in services. Also, there is a positive and significant association between the logarithm of destination CPI and bilateral trade in services.

There is an important dimension of the panel estimates worth stressing. We find a positive association between bilateral service trade and exporter's GDP per capita and population size. Yet, bilateral service trade is also associated with importer's population size. Once we control for population, importer's GDP per capita does not have a significant relation to trade, or it is negative. The reason for the differences between exporter-importer characteristics in accounting for bilateral service trade is difficult to explain by economic theory. According to these estimates, PEI's service imports from all other regions, for example, are a function of its population, but once its population is controlled for, PEI's GDP per capita does not have any additional impact. One possible explanation is that due to federal transfer and equalization payments, demand for service imports tends to be less sensitive to income per capita than to population. In specification 3 , the estimate on exporter log GDP per capita is 0.463 ( $p$-value $=0.007)$, and importer log GDP per capita is 0.066 ( $p$-value $=$ 0.651 ), while coefficient estimates on exporter and importer log population are 0.97

\footnotetext{
${ }^{13}$ We sometimes refer to the region selling services as exporter or origin region, and the region purchasing services as importer or destination region. Supplementary material Table S.3 reports the coefficient estimates on the constant, and year and industry FE included in each of the specifications.

${ }^{14}$ In all the cases, $p$-values $=0.000$. Unless otherwise specified, all reported $p$-values correspond to the null hypothesis of coefficient being 0 .
} 


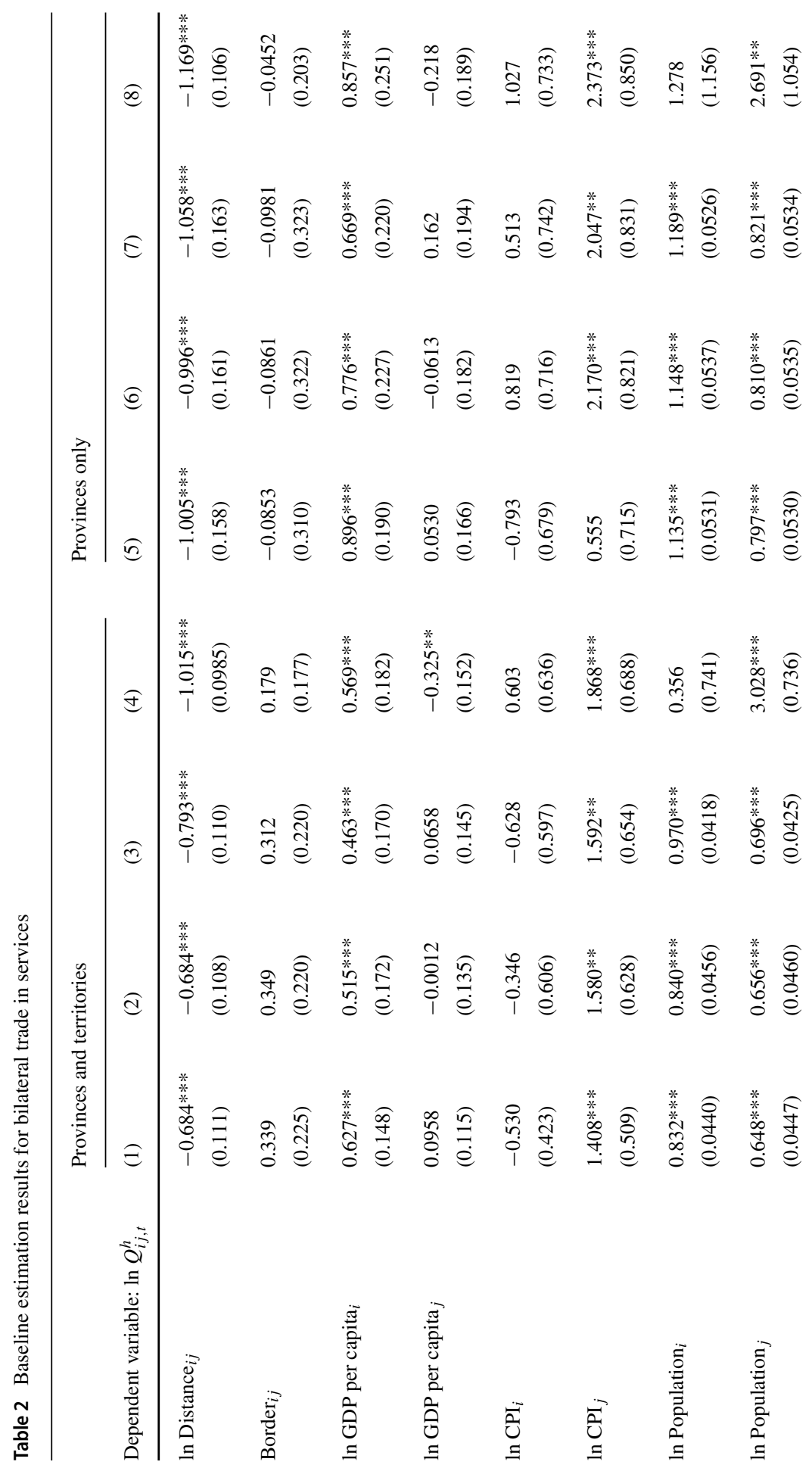




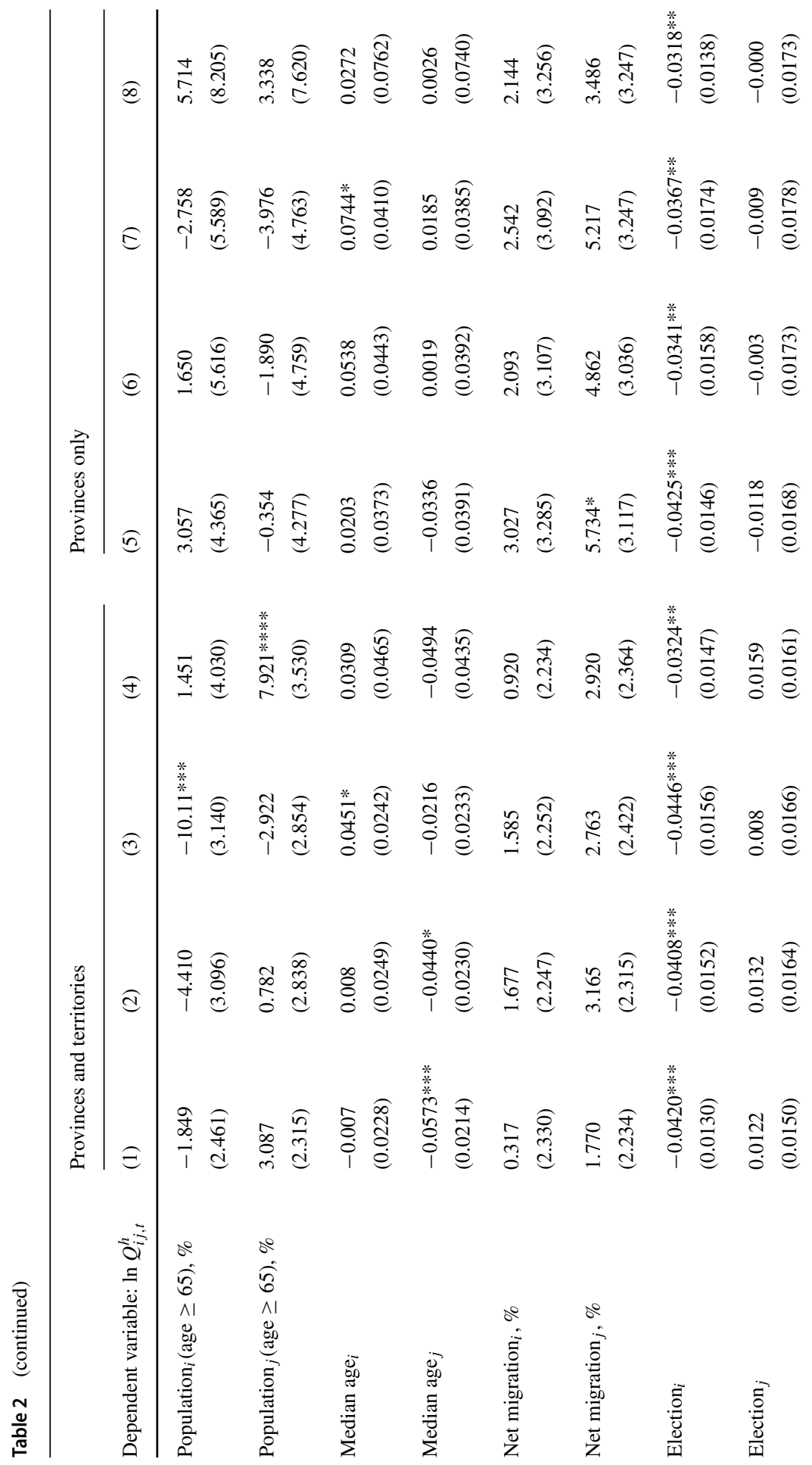




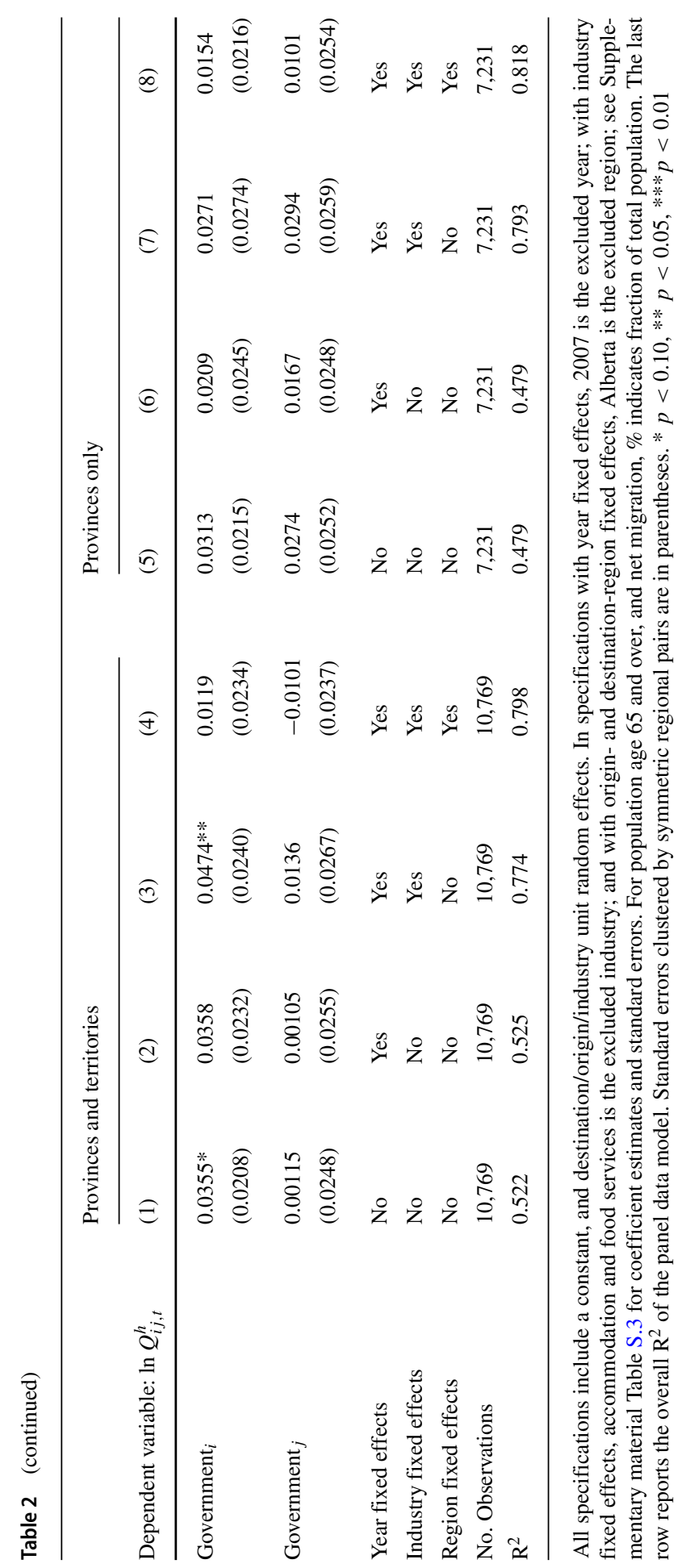


and 0.70 , respectively ( $p$-values $=0.000$ ). In specification 4 , the corresponding estimates and their $p$-values are: exporter log GDP per capita 0.57 (0.002); importer log GDP per capita $-0.33(0.033)$; exporter log population $0.36(0.631)$; importer $\log$ population 3.03 (0.000).

A comparison of the coefficient estimates reported above with those based on inter-provincial service trade only (columns 5-8) yields several differences. First, the estimated elasticity of trade in services with respect to distance is larger than the estimate based on provinces and territories, and close to one (in absolute value)a value predicted by several micro-founded gravity models. We also find a larger elasticity of trade with respect to exporter GDP per capita. At the same time, the coefficient estimates on population and election years are comparable with those from the full set of observations.

In both sets of estimates, including year and industry FE increases the explanatory power of the model considerably compared to those estimates that exclude these effects, but the contributions to $\mathrm{R}^{2}$ of exporter and importer region $\mathrm{FE}$ are marginal. ${ }^{15}$ Our results show that service exports from a region are positively correlated with exporter GDP per capita (income) and importer population, suggesting that while income is a key determinant of supply of interprovincial trade in services, population size is a key determinant of demand for it.

All the results reported in Table 2 are based on observations with non-zero trade values. In order to address the non-random sample-selection concerns due to the exclusion of those observations with zero trade, we used all observations to estimate a probit model (Supplementary material Table S.5). The probit estimates for the impact of distance on service trade are consistent with our previous (GLS) estimates in that distance unambiguously reduces interregional trade in services. The border effect remains insignificant.

To further address the concerns regarding the influence of non-random sample selection on our estimates, we report the coefficient estimates based on model (1), but this time using aggregate interprovincial service trade between any two regions (Table 3). We define aggregate trade in services by summing across all service industries, so that the dependent variable is $\ln \sum_{h} Q_{i j, t}^{h}$. Aggregating across industries yields non-zero values for all observations on interregional trade in services by industry. We report the results with year FE in columns (1) and (3), and year and region (separate for exporters and importers) FE in columns (2) and (4). The downside, however, is that we estimate the effects of distance, border, income, and population without the potentially informative variation across industries, and only rely on variation across origin-destination pairs and over time. Overall, for comparable specifications, the coefficient estimates on log distance are very similar to those reported in Table 2: they are estimated to be about -1 , except in the case of specification 1 using all provinces and territories that do not control for exporter and importer fixed

\footnotetext{
${ }^{15}$ In Table 2, specification 8 , the $\chi^{2}$ statistic for the joint significance test of year FE is 49.52 ( $p$-value $=0.000)$, for the joint significance test of industry fixed effects is 4225.14 ( $p$-value $=0.000)$, and for the joint significance of origin and destination region FE is 203.00 ( $p$-value $=0.000$ ). These test statistics are comparable across alternative specifications.
} 
Table 3 Estimation results for bilateral trade in services: all services

\begin{tabular}{|c|c|c|c|c|}
\hline \multirow[b]{2}{*}{ Dependent variable: $\ln \sum_{h} Q_{i j, t}^{h}$} & \multicolumn{2}{|c|}{ Provinces and territories } & \multicolumn{2}{|c|}{ Provinces only } \\
\hline & (1) & (2) & (3) & (4) \\
\hline In Distance Dij $_{j}$ & $\begin{array}{l}-0.699 * * * \\
(0.139)\end{array}$ & $\begin{array}{l}-1.103 * * * \\
(0.130)\end{array}$ & $\begin{array}{l}-0.962 * * * \\
(0.180)\end{array}$ & $\begin{array}{l}-1.148^{* * * *} \\
(0.123)\end{array}$ \\
\hline Border $_{i j}$ & $\begin{array}{l}0.680 * * \\
(0.307)\end{array}$ & $\begin{array}{l}0.261 \\
(0.243)\end{array}$ & $\begin{array}{l}-0.0152 \\
(0.360)\end{array}$ & $\begin{array}{l}-0.0499 \\
(0.237)\end{array}$ \\
\hline $\ln$ GDP per capita $i$ & $\begin{array}{l}0.461 * * * \\
(0.164)\end{array}$ & $\begin{array}{l}0.0601 \\
(0.174)\end{array}$ & $\begin{array}{l}0.247 \\
(0.198)\end{array}$ & $\begin{array}{l}0.291 \\
(0.225)\end{array}$ \\
\hline ln GDP per capita ${ }_{j}$ & $\begin{array}{l}-0.163 \\
(0.191)\end{array}$ & $\begin{array}{l}-0.638 * * * \\
(0.220)\end{array}$ & $\begin{array}{l}-0.0133 \\
(0.192)\end{array}$ & $\begin{array}{l}-0.248 \\
(0.197)\end{array}$ \\
\hline $\ln \mathrm{CPI}_{i}$ & $\begin{array}{l}-0.0888 \\
(0.816)\end{array}$ & $\begin{array}{l}0.606 \\
(0.725)\end{array}$ & $\begin{array}{l}1.208 \\
(1.054)\end{array}$ & $\begin{array}{l}1.637 * \\
(0.968)\end{array}$ \\
\hline $\ln \mathrm{CPI}_{j}$ & $\begin{array}{l}1.506^{* *} \\
(0.692)\end{array}$ & $\begin{array}{l}1.994 * * * \\
(0.668)\end{array}$ & $\begin{array}{l}1.401 * \\
(0.812)\end{array}$ & $\begin{array}{l}1.563 * * \\
(0.742)\end{array}$ \\
\hline ln Population $_{i}$ & $\begin{array}{l}0.999 * * * \\
(0.0491)\end{array}$ & $\begin{array}{l}3.611 * * * \\
(0.721)\end{array}$ & $\begin{array}{l}1.173 * * * \\
(0.0550)\end{array}$ & $\begin{array}{l}4.715^{* * * *} \\
(1.013)\end{array}$ \\
\hline ln Population P $_{j}$ & $\begin{array}{l}0.767 * * * \\
(0.0470)\end{array}$ & $\begin{array}{l}3.698 * * * \\
(0.934)\end{array}$ & $\begin{array}{l}0.856 * * * \\
(0.0610)\end{array}$ & $\begin{array}{l}3.161 * * \\
(1.587)\end{array}$ \\
\hline Population $_{i}($ age $\geq 65), \%$ & $\begin{array}{l}-5.559 * \\
(3.107)\end{array}$ & $\begin{array}{l}3.346 \\
(4.255)\end{array}$ & $\begin{array}{l}-3.731 \\
(4.376)\end{array}$ & $\begin{array}{l}5.101 \\
(6.487)\end{array}$ \\
\hline Population $_{j}($ age $\geq 65), \%$ & $\begin{array}{l}0.242 \\
(3.071)\end{array}$ & $\begin{array}{l}5.568 \\
(3.443)\end{array}$ & $\begin{array}{l}-7.724 \\
(5.082)\end{array}$ & $\begin{array}{l}-6.637 \\
(5.834)\end{array}$ \\
\hline Median age $_{i}$ & $\begin{array}{l}0.00663 \\
(0.0247)\end{array}$ & $\begin{array}{l}0.0570 \\
(0.0480)\end{array}$ & $\begin{array}{l}0.0605 \\
(0.0383)\end{array}$ & $\begin{array}{l}0.0818 \\
(0.0613)\end{array}$ \\
\hline Median age $_{j}$ & $\begin{array}{l}-0.0393 \\
(0.0298)\end{array}$ & $\begin{array}{l}0.0124 \\
(0.0450)\end{array}$ & $\begin{array}{l}0.0593 \\
(0.0466)\end{array}$ & $\begin{array}{l}0.121 * \\
(0.0685)\end{array}$ \\
\hline Net migration $_{i}$, & $\begin{array}{l}0.498 \\
(3.540)\end{array}$ & $\begin{array}{l}-0.315 \\
(3.151)\end{array}$ & $\begin{array}{l}-1.493 \\
(3.908)\end{array}$ & $\begin{array}{l}-4.035 \\
(3.633)\end{array}$ \\
\hline Net migration $_{j}$, & $\begin{array}{l}3.429 \\
(2.952)\end{array}$ & $\begin{array}{l}2.781 \\
(3.205)\end{array}$ & $\begin{array}{l}4.779 * * \\
(2.372)\end{array}$ & $\begin{array}{l}2.225 \\
(3.131)\end{array}$ \\
\hline Election $_{i}$ & $\begin{array}{l}-0.0274 \\
(0.0194)\end{array}$ & $\begin{array}{l}-0.0211 \\
(0.0192)\end{array}$ & $\begin{array}{l}0.00045 \\
(0.0139)\end{array}$ & $\begin{array}{l}0.00032 \\
(0.0127)\end{array}$ \\
\hline
\end{tabular}


Table 3 (continued)

\begin{tabular}{|c|c|c|c|c|}
\hline \multirow[b]{2}{*}{ Dependent variable: $\ln \sum_{h} Q_{i j, t}^{h}$} & \multicolumn{2}{|c|}{ Provinces and territories } & \multicolumn{2}{|c|}{ Provinces only } \\
\hline & (1) & (2) & (3) & (4) \\
\hline \multirow[t]{2}{*}{ Election $_{j}$} & 0.0222 & 0.0257 & -0.00955 & -0.0103 \\
\hline & $(0.0176)$ & $(0.0178)$ & $(0.0181)$ & $(0.0192)$ \\
\hline \multirow[t]{2}{*}{ Government $_{i}$} & 0.0318 & 0.0074 & -0.00862 & -0.00792 \\
\hline & $(0.0295)$ & $(0.0288)$ & $(0.0292)$ & $(0.0267)$ \\
\hline \multirow[t]{2}{*}{ Government $_{j}$} & 0.00978 & -0.00362 & $0.0681 * *$ & $0.0697 * *$ \\
\hline & $(0.0332)$ & $(0.0302)$ & $(0.0330)$ & $(0.0340)$ \\
\hline Year fixed effects & Yes & Yes & Yes & Yes \\
\hline Region fixed effects & No & Yes & No & Yes \\
\hline No. Observations & 1,088 & 1,088 & 630 & 630 \\
\hline $\mathrm{R}^{2}$ & 0.892 & 0.931 & 0.906 & 0.948 \\
\hline
\end{tabular}

All specifications include a constant, and destination-origin unit random effects. In specifications with year fixed effects, 2007 is the excluded year; and with origin- and destination-region fixed effects, Alberta is the excluded region. Coefficient estimates and standard errors of these fixed effects are available upon request. For population age 65 and over, and net migration, \% indicates fraction of total population. The last row reports the overall $\mathrm{R}^{2}$ of the panel data model. Standard errors clustered by symmetric regional pairs are in parentheses. $* p<0.10, * * p<0.05, * * * p<0.01$

effects, in which case the elasticity is about -0.7 . Again, with the exception of specification 1, the border effect is estimated to be statistically indistinguishable from zero. We conclude that aggregation across service industries that addresses the data selection issue by eliminating observations with zero trade values does not have a material impact on the estimated average trade elasticity of distance.

With regards to the remaining coefficient estimates, after aggregating across industries, the estimates no longer point to a positive relation between exporter GDP and bilateral service trade (except in specification 1). By contrast, the coefficient estimates on both exporter and importer log population variables are positive and large ( $p$-values $=0.000)$, except in specification 4 where the $p$-value for the coefficient on importer log population is 0.046 . The reason industry-level and aggregate data put different weights on the impact of these economic variables on bilateral service trade might be due to the prevailing heterogeneity across industries in the trade elasticity of distance, income, and population; a possibility that we explore in the next section.

\subsection{Estimates by Industry}

We now turn to the extension of the baseline model whereby we estimate (1) using more flexible specifications by allowing the regressors to have heterogeneous associations with bilateral service trade flows at the industry level. We do this in two different specifications. In the first specification, we allow distance to have industryspecific effect on interprovincial trade (an "interaction" term; Table 4). In the second specification, we estimate (1) separately for each industry $\left(\beta^{h}\right.$; Table 5). 


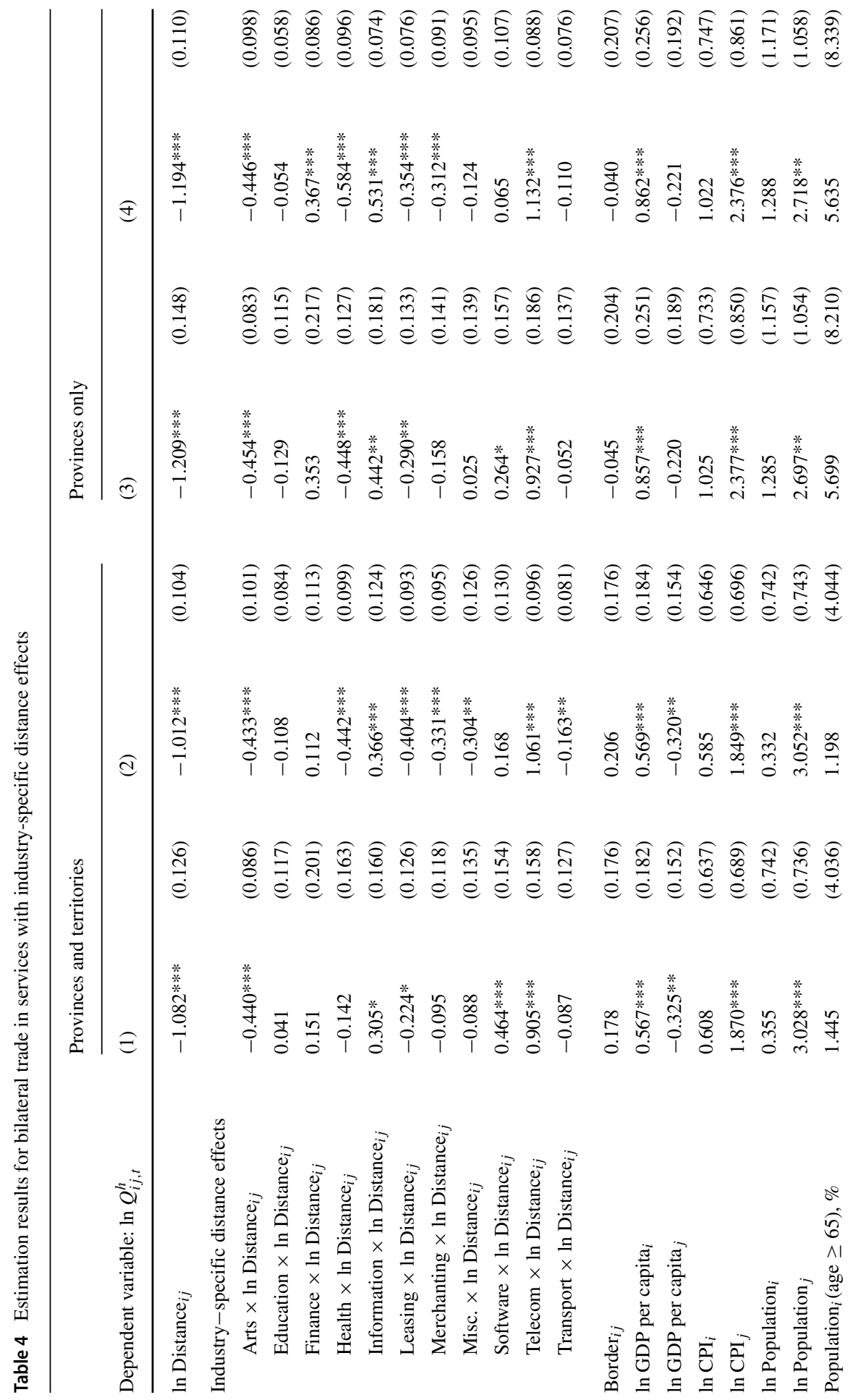




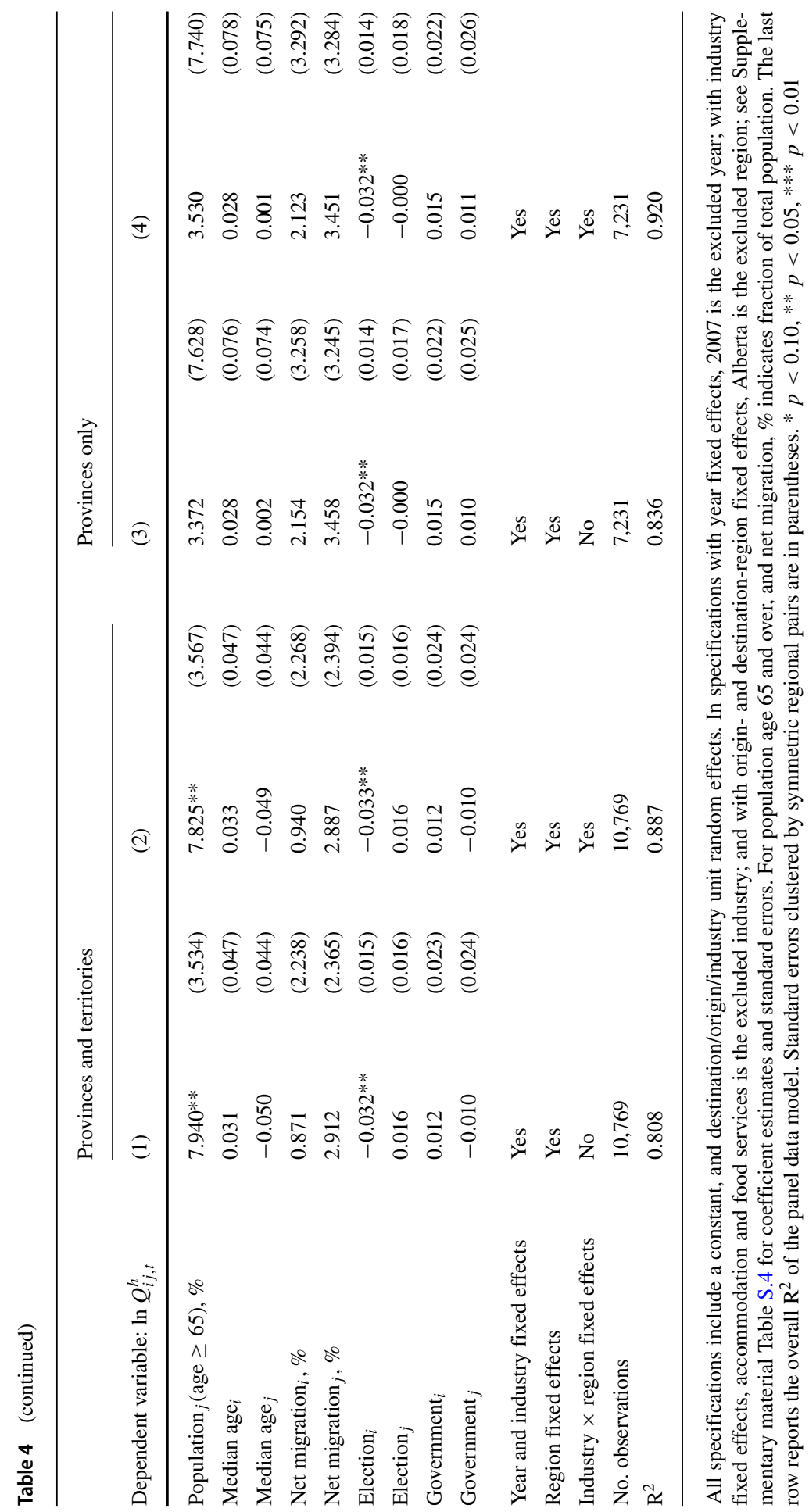




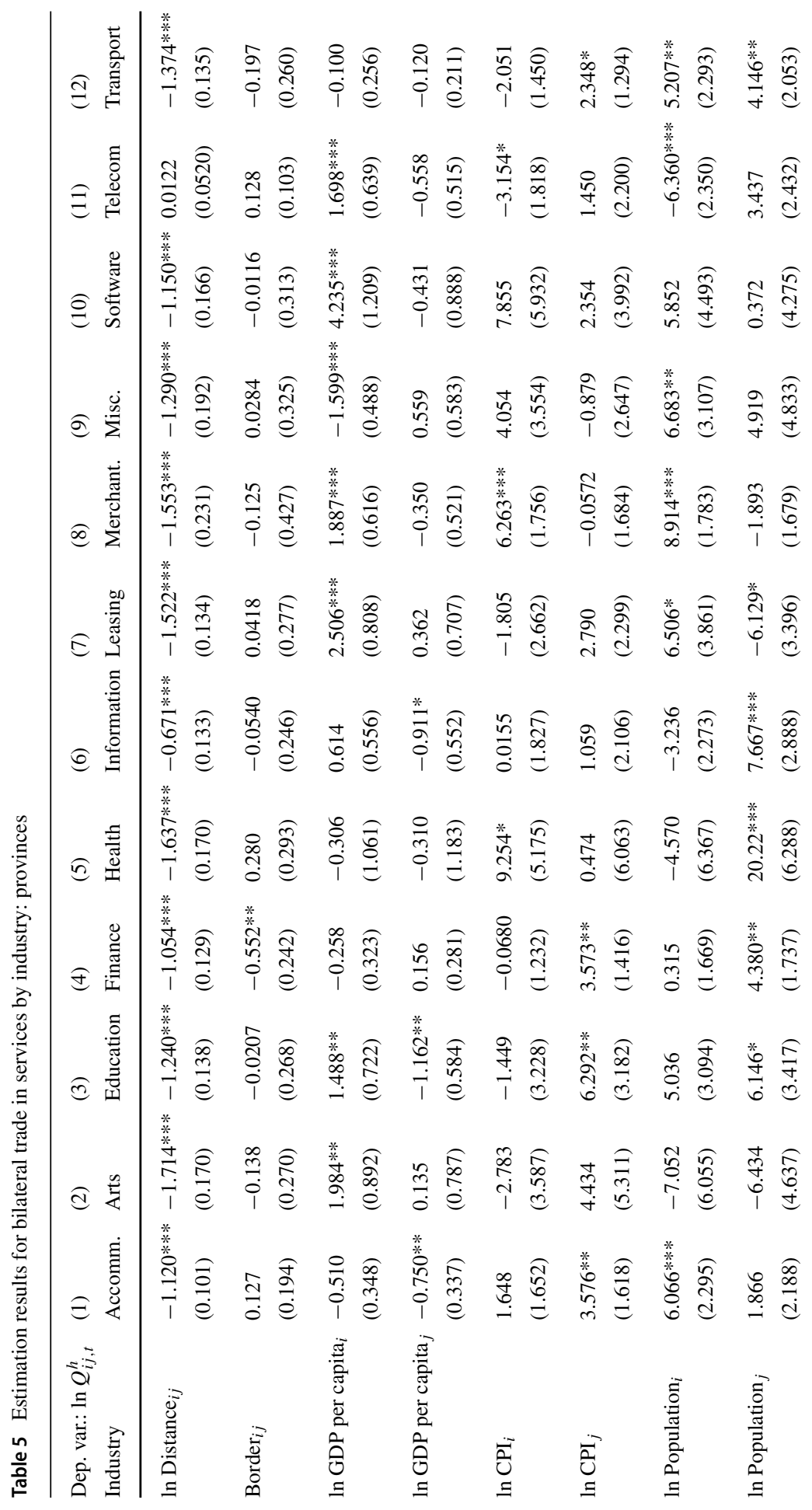




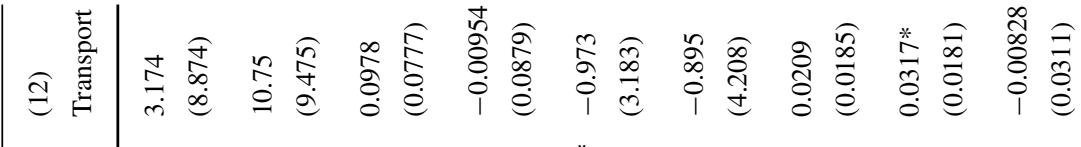

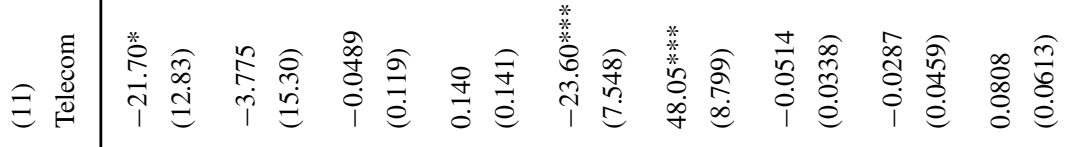

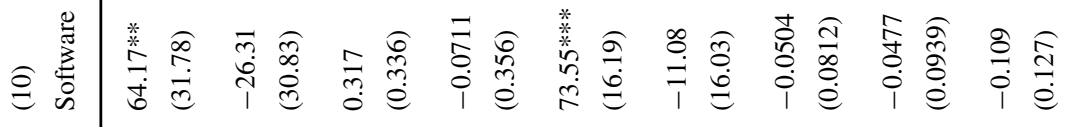

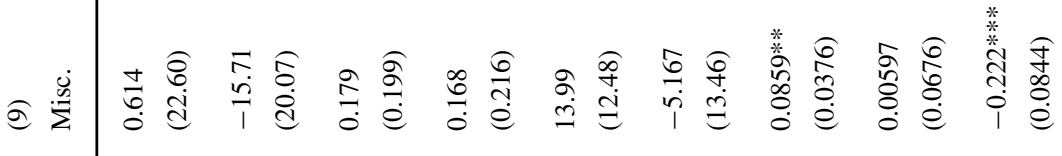

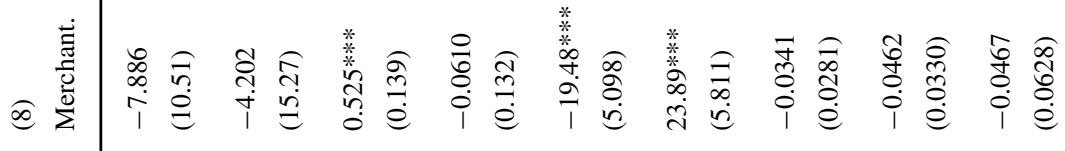

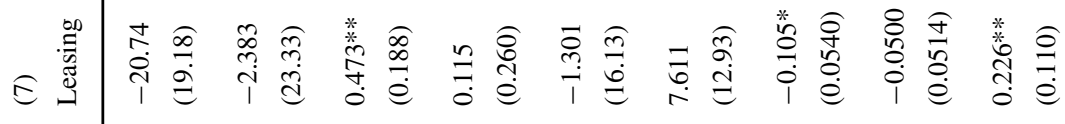

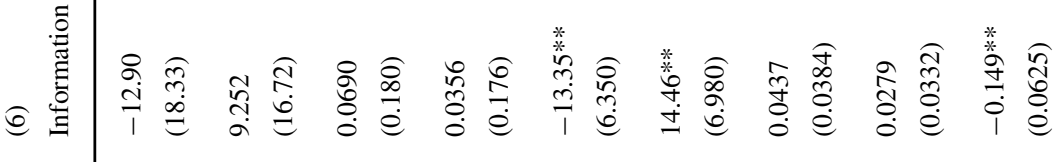

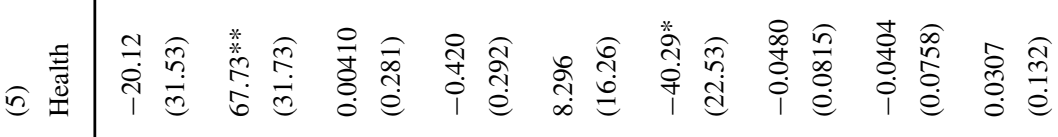

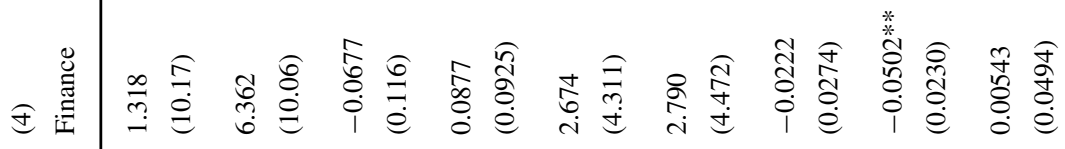

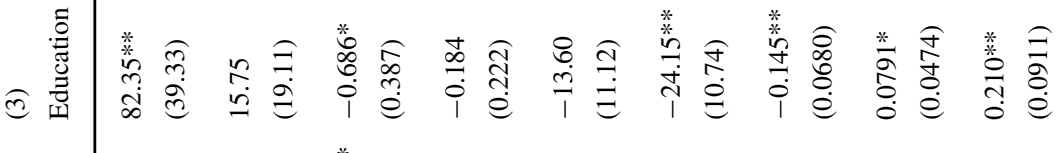

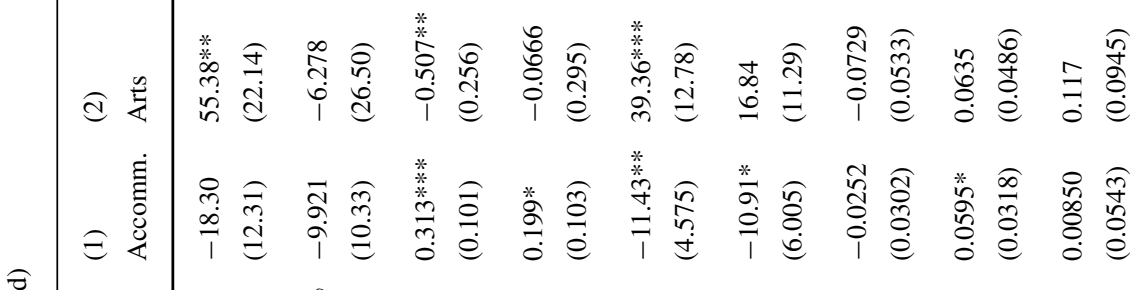

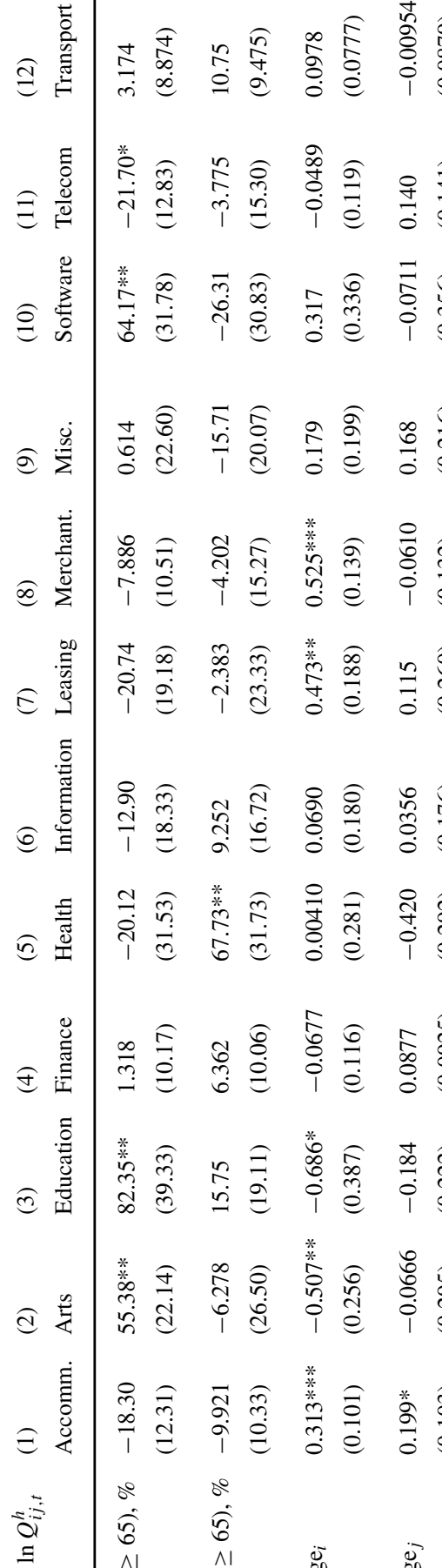

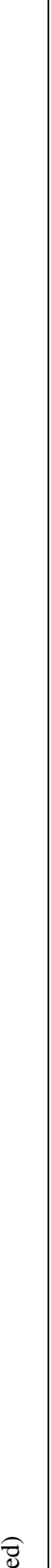




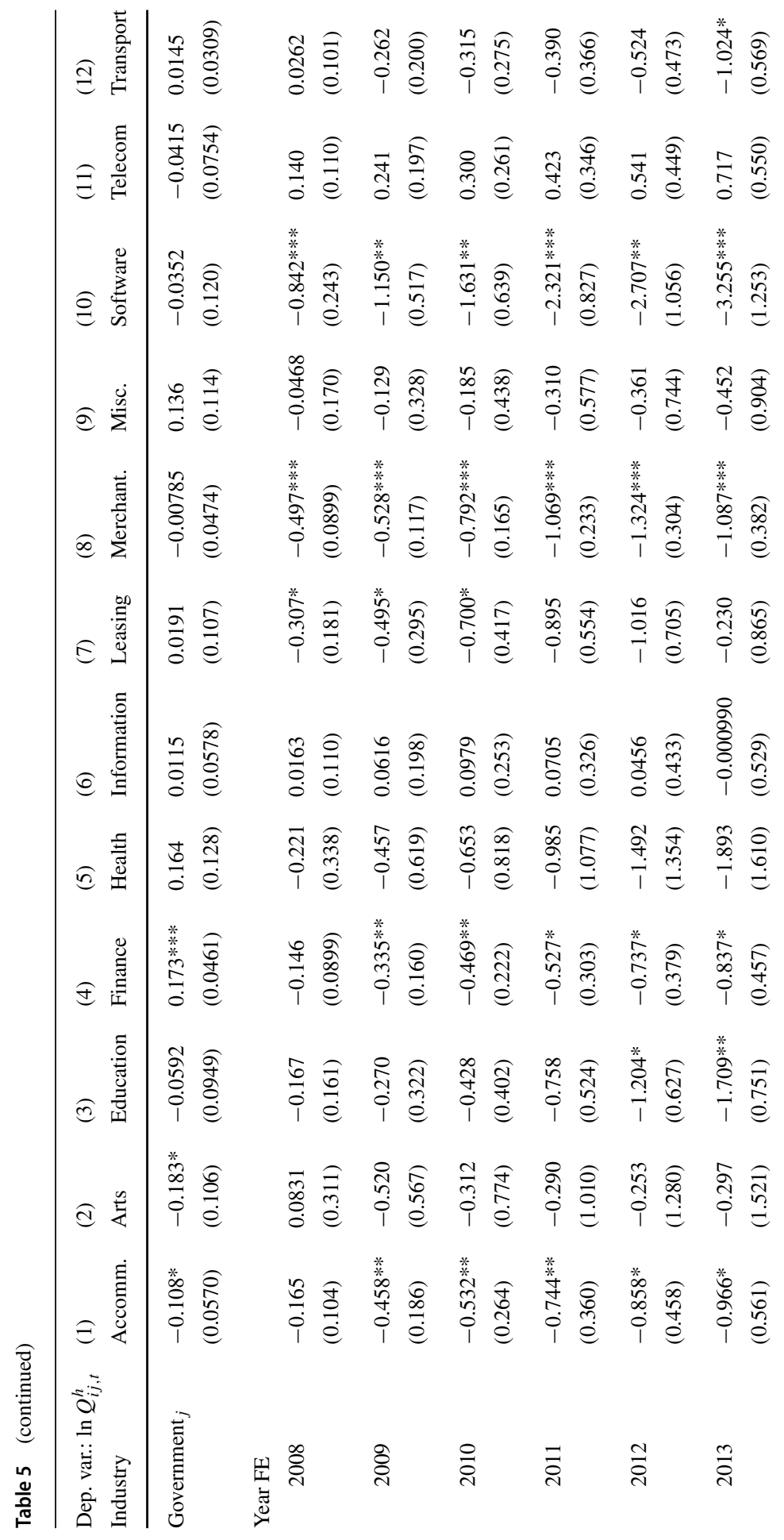




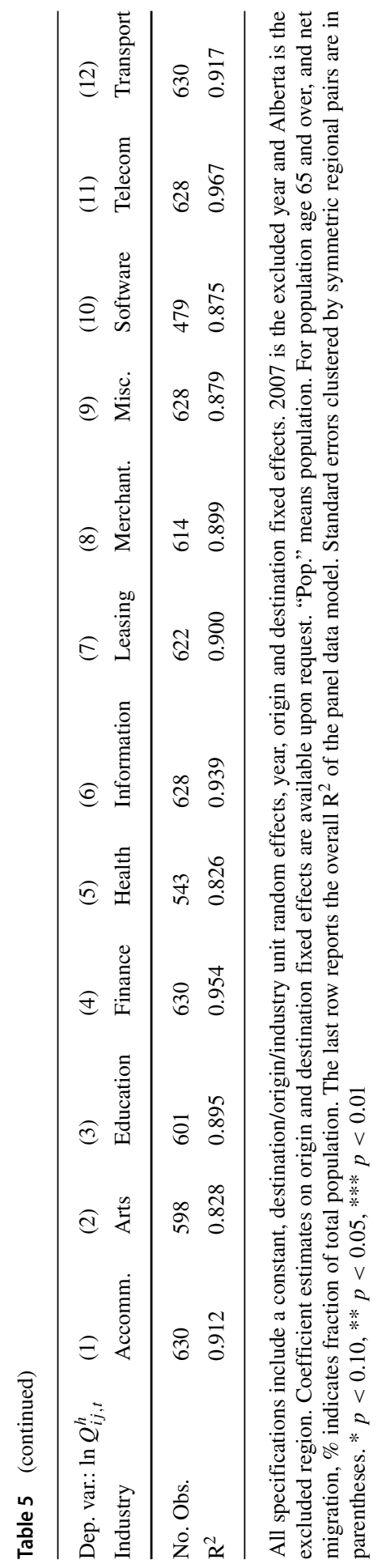


Our inclusion of these interaction terms is based on a number of economic factors that could impact trade in services in a given industry differently than in another one. Consider, for example, Health and Transportation. The impact of physical distance on cross-border medical service trade could be different from that on transportation: while provincial regulations and interprovincial agreements between contiguous regions are the most critical drivers of trade in medical services, transportation services are largely driven by interprovincial trade in goods. As a result, Health would be highly sensitive to distance, whereas Transportation exists because of the physical distance between the location of production (or port of entry) and consumption of goods.

In specifications reported in Table 4 the effect of distance on regional service trade can vary across industries, while all other regressors are restricted to have the same effect on interprovincial service trade regardless of industry. All the models in Table 4 include year and region fixed effects. Columns 2 and 4 also include interaction terms for industry-origin and industry-destination fixed effects. Our estimates indicate considerable industry-level variation in terms of the effects of distance on trade values. Trade values in four service industries are particularly affected by distance: Arts, Health (especially when only provincial data are used), Leasing, and Merchanting. Trade in Telecommunications is practically unaffected by distance. Our coefficient estimates on other regressors reported in Table 4 are consistent with those reported in Table 2. We continue to find that trade values increase with exporter income and importer population, and that elections in the exporter region tend to be associated with lower bilateral service trade.

One limitation of our original specification (1) and its extension above with industry-specific distance effects is that they both impose the restriction that income (GDP per capita) and population effects are uniform across industries. ${ }^{16}$ The degree of complementarity in production between goods and services is likely to be another factor driving trade in services at the industry level. For example, the sale of photovoltaic solar panels by one province (Ontario) to another province cannot be thought of as independent from the availability of engineering and technical services for installing and maintaining such solar panels elsewhere. Complementarity in production would thus imply that distance may reduce merchandise trade not only because transporting goods from where they were produced is costly, but also because complementary services are simply not available in the destination region, and service providers are often equally, if not more, expensive to transport. Economic and statistical considerations thus motivate us to specify a highly flexible model and estimate Eq. (1) separately for each service industry and for provinces only (Table 5).

\footnotetext{
${ }^{16}$ In more concrete terms, one may not think that services provided by call centres (Telecommunications) and engineering services have identical income elasticities for both exporter and importer regions and respond similarly to distance. Call centres tend to be selected into low income provinces, and distance to final consumers may have no particular significance. Whereas engineering services tend to locate closer to large markets and will be affected by physical distance. If income elasticities of demand for individual services provided by industries are different from each other and the physical distance between the two regions have differential impact across industries, then the industry-specific distance estimates would capture a combination of industry-specific distance and income elasticities. However, given that the correlation between distance and GDP per capita is low, we do not expect a substantial bias.
} 
Our coefficient estimates on distance are strongly negative for all industries, except Telecommunications where trade is not affected by distance. We find no separate influence of a border on interprovincial trade in any of the industries, once the physical distance between the two provinces is controlled for (except Finance). Consistent with our estimates in Table 4, Arts, Health, Leasing, and Merchanting have the highest (in absolute value) elasticity of trade with respect to distance. Despite the declining importance of retail banking, Finance remains a sector that is affected by distance. Whether geographic concentration of the financial industry in a few city centres is partly responsible for the negative impact of distance on interprovincial trade in services remains an open question. Similarly, despite the highly specialized nature of services offered by engineering and architectural services, transportability of their qualified personnel remains a constraint on their interprovincial trade. At the same time, we do find it intriguing that distance has a negative impact on Leasing and Software, with an indirect inference that, in both cases, geographic proximity and face-to-face business dealings remain important considerations for business. Telecommunications is the industry that is least affected by physical distance. One could argue that distance is precisely the problem that this industry solves.

Our estimates in Tables 4 and 5 demonstrate that the elasticities of trade in services with respect to distance and income vary considerably across industries. While the average effect of distance on trade in services can be estimated using either baseline and aggregate service industry specifications (Tables 2 and 3) or industryspecific specifications (Tables 4 and 5), one advantage of using the industry-level estimates is that they underscore the substantial heterogeneity across service industries in the elasticity of trade with respect to distance. At the same time, a comparison of the corresponding estimates in Tables 4 and 5, specification 4 demonstrates that the industry-specific elasticity of trade with respect to distance is not influenced by industry-specific income elasticity terms, as allowed for in Table 5. ${ }^{17}$ Therefore, the parsimonious model underlying Table 4, specification 4 is sufficient to identify the elasticity of interregional trade in services with respect to distance at the industry level. In addition, a comparison of the relevant estimation results in Tables 4 and 5 shows that there is substantial heterogeneity in the elasticity of trade with respect to both exporter and importer incomes, as well as with respect to exporter and importer populations: coefficients range from large negative to large positive.

\section{Conclusion}

We provide new evidence on the effects of distance, borders, income, and population size on trade in services using industry level data from Canadian provinces and territories for the period 2007-2013. We estimate the model by using a random effect panel specification with year, region, industry-origin, and industry-destination fixed effects. We find that distance is a barrier to trade in services. Our estimates of aver-

\footnotetext{
${ }^{17}$ Given that Table 5 reports the coefficient estimates for province-pairs only, we use Table 4 specification 4 for comparison purposes.
} 
age trade in services elasticity with respect to distance range from -1.02 to -1.17 . In their survey, Head and Mayer (2014) report that, for trade in merchandise, the median estimate of the coefficient on the log distance is -0.89 , and the mean estimate is -0.93 (s.e. 0.40). Estimates based on structural gravity model are larger: the median estimate is -1.14 and the mean estimate is -1.10 (s.d. 0.41 ). They also report that the coefficient estimates on the border variable ("contiguity") are typically positive but have a large standard deviation, which encompasses no effect, a finding that is consistent with our estimates.

However, our estimates show that average trade-in-services elasticities mask substantial cross-industry differences. Our preferred specification allows for industryspecific distance effects. While industry-specific estimates of the elasticity of trade in services with respect to distance are close to one in absolute value, distance matters much more for trade in Arts and Health, and much less for Telecommunications. We also find striking differences across industries in the estimated elasticities of trade in services with respect to exporter and importer incomes, which underscore the importance of industry-level longitudinal data to account for the key determinants of trade in services.

\section{Appendix A: Data Sources and Variable Definitions}

Table 6 lists our variables. Here we document the data sources for those not described elsewhere in the text.

Service Sales Provincial Input-Output Tables, Cansim table 12-10-0088-01, annual, Statistics Canada.

Distance Crow fly distance between Canadian provincial and territorial capitals, miles, http://www.tjpeiffer.com/crowflies.html.

Table 6 Variable descriptions and shorthand references

1. Service sales, in current prices and logs: $\ln Q_{i j}^{h}$

2. Distance between capital cities in kilometres: In Distance $i j$

3. Common border ( 1 if there is a border, 0 otherwise): Border $_{i j}$

4. Gross domestic product per capita, in current prices and logs: In GDP per capita

5. Total population (in logs) in the destination and origin regions: In Population

6. Consumer price index (in logs) in the destination and origin regions, ln CPI

7. Fraction of population age 65 and above in the destination and origin regions: Population(age $\geq 65), \%$

8. Median age of the population, in years: Median age

9. Net annual migration in the destination and origin regions as a fraction of total population: Net migration, $\%$

10. Election year dummy variables for destination and origin regions (takes value 1 if election year, 0 otherwise): Election

11. Continuity in government (takes value 1 if there is a change in governing political party or coalition): Government 
Gross Domestic Product Cansim Table 384-0038 Gross domestic product, expenditure-based, provincial and territorial, annual, Statistics Canada.

Consumer Price Index Cansim Table 326-0021, Consumer Price Index (CPI), annual (2002=100), Statistics Canada.

Population, Population Age 65+, Median Age Cansim Table 17-10-0060-01, Estimates of population as of July 1st, by marital status or legal marital status, age and sex, Statistics Canada.

Net Migration Cansim Table 17-10-0085-01, Components of population growth by census division, age group and sex, annual, based on the Standard Geographical Classification (SGC) 2011, Statistics Canada.

Election and Government https://en.wikipedia.org/wiki/Timeline_of_Canadian_ elections

Table 7 Correlation matrix: provinces and territories

\begin{tabular}{|c|c|c|c|c|c|c|c|c|c|}
\hline Variable & $\begin{array}{l}\ln \\
\text { GDPpc }\end{array}$ & ln Pop & $\ln \mathrm{CPI}$ & $\begin{array}{l}\text { Pop } \\
\geq 65\end{array}$ & $\begin{array}{l}\text { Median } \\
\text { age }\end{array}$ & $\begin{array}{l}\text { Net } \\
\text { migrat. }\end{array}$ & Elect. & Govern. & $\begin{array}{l}\ln \\
\text { Distance }\end{array}$ \\
\hline \multicolumn{10}{|l|}{ Exporter } \\
\hline $\ln$ GDPpc & 1.000 & & & & & & & & \\
\hline $\ln$ Pop & -0.332 & 1.000 & & & & & & & \\
\hline $\ln \mathrm{CPI}$ & 0.477 & 0.260 & 1.000 & & & & & & \\
\hline Pop $\geq 65$ & -0.613 & 0.655 & 0.170 & 1.000 & & & & & \\
\hline Median age & -0.495 & 0.495 & 0.134 & 0.913 & 1.000 & & & & \\
\hline Net migration & 0.039 & 0.213 & 0.274 & 0.123 & 0.193 & 1.000 & & & \\
\hline Election & -0.004 & 0.066 & -0.111 & 0.009 & -0.015 & -0.042 & 1.000 & & \\
\hline Government & -0.226 & 0.047 & -0.078 & 0.203 & 0.167 & -0.049 & 0.431 & 1.000 & \\
\hline \multicolumn{10}{|l|}{ Importer } \\
\hline ln GDPpc & -0.041 & 0.029 & 0.084 & 0.078 & 0.055 & -0.003 & -0.008 & 0.000 & \\
\hline $\ln$ Pop & 0.029 & -0.083 & -0.013 & -0.053 & -0.040 & -0.017 & -0.006 & -0.004 & \\
\hline $\ln \mathrm{CPI}$ & 0.084 & -0.013 & 0.406 & 0.086 & 0.044 & -0.009 & -0.087 & -0.036 & \\
\hline Pop $\geq 65$ & 0.078 & -0.053 & 0.086 & -0.061 & -0.064 & -0.014 & -0.016 & -0.021 & \\
\hline Median age & 0.055 & -0.040 & 0.044 & -0.064 & -0.076 & -0.015 & -0.008 & -0.017 & \\
\hline Net migration & -0.003 & -0.017 & -0.009 & -0.014 & -0.015 & -0.044 & -0.005 & -0.017 & \\
\hline Election & -0.008 & -0.006 & -0.087 & -0.016 & -0.008 & -0.005 & 0.080 & -0.031 & \\
\hline Government & 0.000 & -0.004 & -0.036 & -0.021 & -0.017 & -0.017 & -0.031 & -0.040 & \\
\hline \multicolumn{10}{|l|}{ Common } \\
\hline In Distance & 0.174 & -0.110 & 0.004 & -0.173 & -0.125 & 0.083 & -0.011 & -0.082 & 1.000 \\
\hline Border & 0.076 & -0.032 & 0.014 & -0.053 & -0.067 & -0.104 & 0.010 & 0.005 & -0.644 \\
\hline
\end{tabular}

"GDPpc" is GDP per capita; "Pop $\geq 65$ " is Population(age $\geq 65$ ), \%. See Table 6 for the remaining variable descriptions. Columns refer to exporter characteristics 
Supplementary Information The online version contains supplementary material available at https://doi.org/10.1007/s11079-021-09629-3.

Acknowledgements We thank two anonymous referees, Tess Cyrus, James Sawler and conference participants at CEA and ACEA meetings for suggestions and discussions, Chenlu Shao for excellent research assistance, and Denis Caron (Statistics Canada) for leading us to the data sources. This paper is supported in part by the Atlantic Canada Opportunities Agency (ACOA) under the Atlantic Policy Research Initiative, which provides a vehicle for the analysis of key socio-economic policy issues in Atlantic Canada. The views expressed in this study do not necessarily reflect the views of ACOA or of the Government of Canada. The authors are responsible for the accuracy, reliability and currency of the information.

Funding This paper is supported in part by the Atlantic Canada Opportunities Agency (ACOA) under the Atlantic Policy Research Initiative, which provides a vehicle for the analysis of key socio-economic policy issues in Atlantic Canada. The views expressed in this study do not necessarily reflect the views of ACOA or of the Government of Canada. The authors are responsible for the accuracy, reliability and currency of the information. The authors declare no competing financial interest.

Availability of data and material Data are public and the data set used in the paper is available from the authors upon request.

Code Availability STATA $^{\circledR}$ code is available from the authors upon request.

\section{Declarations}

Competing interests The authors declare no competing financial interest.

\section{References}

Anderson JE, Milot CA, Yotov YV (2014) How much does geography deflect services trade? Canadian answers. Int Econ Rev 55(3):791-818

Benz S (2017) Services trade costs. OECD Trade Policy Papers

Boulatoff C, İşcan TB (2018) An international and interprovincial perspective on Canada's trade in services. Dalhousie University, mimeo

Duval Y, Saggu A, Utoktham C (2015) Value added trade costs in goods and services. United Nations ESCAP Trade and Investment Working Paper Series

Findlay R, O'Rourke K (2007) Power and plenty: Trade, war and the world economy in the second millenium. Princeton University Press, Princeton and Oxford

Francois J, Hoekman B (2010) Services trade and policy. J Econ Lit 48:642-692

Fuchs VR (1968) The service economy. Columbia University Press for NBER, New York

Généreux PA, Langen B (2002) The derivation of provincial (inter-regional) trade flows: The Canadian experience. Manuscript

Gervais A (2018) Estimating the impact of country level policy restrictions on services trade. Rev Int Econ 26(4):743-767

Goldfarb D (2013) Canada's growing but “invisible” trade: services. Ottawa: Conference Board of Canada. http://www.conferenceboard.ca/economics/hot_eco_topics/default/13-05-29/canada_s_growing_but_

$\%$ E2\%80\%9Cinvisible\%E2\%80\%9Dtrade_services.aspx

Grady P, MacMillan K (1998) Why is interprovincial trade down and international trade up? Can Bus Econ 6(4):26-35

Head K, Mayer T (2014) Gravity equations: Workhorse, toolkit, and cookbook. In: Gopinath G, Helpman E, Rogoff K (eds) Handbook of international economics, volume 4 of Handbook of International Economics. Elsevier, pp 131-195

Helliwell JF (1997) National borders, trade and migration. Pac Econ Rev 2(3):165-185 
Kimura F, Lee H-H (2006) The gravity equation in international trade in services. Rev World Econ 142(1):92-121

Kox H, Nordås HK (2007) Services trade and domestic regulation. OECD Trade Policy Papers 49

Lewis LT, Monarch R, Sposi M, Zhang J (2018) Structural change and global trade. International Finance Discussion Papers 1225

Maurer A, Magdeleine J, Lanz R (2016) Measuring trade in services in a world of global value chains. In: Sauvé P, Roy M (eds) Research handbook on trade in services. Edward Elgar, Northampton MA, pp 42-65

McCallum J (1995) National borders matter: Canada-U.S. regional trade patterns. Am Econ Rev 85(3):615-623

Minford A, Xu Y (2018) Classical or gravity? which trade model best matches the UK facts? Open Econ Rev 29(3):579-611

Miroudot S, Sauvage J, Shepherd B (2013) Measuring the cost of international trade in services. World Trade Rev 12(4):719-735

Miroudot S, Shepherd B (2014) The paradox of 'preferences': Regional trade agreements and trade costs in services. World Econ 37(12): 1751-1772

Nordås KH (2018) What drives trade in services? Lessons from the Nordics. Appl Econ 50(33):3532-3545

Palladini J (2015) Canada's big opportunity in China is services, not just resources. Canadian Business. http://www.canadianbusiness.com/blogs-and-comment/canada-china-services-export-opportunity/

Schettkat R, Yoncarini L (2006) The shift to services employment: a review of the literature. Struct Chang Econ Dyn 17:127-147

Statistics Canada (2013) Modernization of the input-output tables. Industry Accounts Division

Tito M (2019) Exporters of services: A look at U.S. exporters outside of the manufacturing sector. Board of Governors of the Federal Reserve System, FEDS Working Paper No. 2019-063

van der Marel E (2016a) Ricardo does services: Service sector regulation and comparative advantage in goods. In: Sauvé P, Roy M (eds) Research handbook on trade in services. Edward Elgar, Northampton, MA, pp 85-106

van der Marel E (2016b) The potential to enhance Canada's services trade in CETA, TPP and TiSA. In: Tapp S, Assche AV, Wolfe R (eds) Redesigning canadian trade policies for new global realities, volume 6 of The Art of the State. Montreal Institute for Research on Public Policy

Walsh K (2008) Trade in services: Does gravity hold? J World Trade 42(2):315-334

Wernerheim CM, Waples MJ (2013) Demand patterns and Canada's trade in services. IEEP 10(2):159-181

Wooldridge J (2010) Econometric analysis of cross section and panel data, 2nd edn. MIT Press, Cambridge World Bank (2017) Trade in services database

World Trade Organization (2013) General agreement on trade in services: An introduction. https://www. wto.org/english/tratop_e/serv_e/gsintr_e.pdf

Wrona J (2017) Border effects without borders: What divides Japan's internal trade? CESifo Working Paper No. 7056

Publisher's Note Springer Nature remains neutral with regard to jurisdictional claims in published maps and institutional affiliations. 